Original article

\title{
Simultaneous determination of iron (II) and ascorbic acid in pharmaceuticas based on flow sandwich technique
}

\author{
Christina Vakh*, Elena Freze, Alexsey Pochivalov, Ekaterina Evdokimova, Mihail Kamencev, \\ Leonid Moskvin, Andrey Bulatov
}

Department of Analytical Chemistry, Institute of Chemistry, Saint Petersburg State University, Saint Petersburg, pr. Universitetskij 26, 198504, Russia

\section{A R T I C L E I N F O}

\section{Article history:}

Received 13 January 2015

Received in revised form 7 March 2015

Accepted 31 March 2015

Available online 8 April 2015

\section{Keywords:}

Automation of pharmaceutical analysis

Flow analysis

Sandwich technique

Iron (II)

Ascorbic acid

\begin{abstract}
A B S T R A C T
The simple and easy performed flow system based on sandwich technique has been developed for the simultaneous separate determination of iron (II) and ascorbic acid in pharmaceuticals. The implementation of sandwich technique assumed the injection of sample solution between two selective reagents and allowed the carrying out in reaction coil two chemical reactions simultaneously: iron (II) with 1,10-phenanthroline and ascorbic acid with sodium 2,6-dichlorophenolindophenol. For achieving of excellent repeatability and considerable reagent saving the various parameters such as flow rate, sample and reagent volumes, reaction coil length were also optimized. The limits of detection (LODs) obtained by using the developed flow sandwich-type approach were $0.2 \mathrm{mg} \mathrm{L}^{-1}$ for iron (II) and $0.7 \mathrm{mg} \mathrm{L}^{-1}$ for ascorbic acid. The suggested approach was validated according to the following parameters: linearity and sensitivity, precision, recoveries and accuracy. The sampling frequency was $41 \mathrm{~h}^{-1}$.
\end{abstract}

(c) 2015 Elsevier Inc. All rights reserved.

\section{Introduction}

Pharmaceuticals are the chemical substances containing one or several pharmacologically active ingredients and excipients - substances which are added to a prescription in order to confer a suitable consistency or form of the drug as well as to affect the bioavailability of the active ingredients (Jackson, Young, \& Pant, 2000; Pifferi \& Restani, 2003; World Health Organization, 2007). The quality control of pharmaceuticals is a key factor at all stages of their development and production. In recent years, the international pharmacopoeia requirements and standards related to the quality control of pharmaceuticals become stricter (Pimenta, Montenegro, Araujo, \& Martınez Calatayud, 2006; World Health Organization, 2007). This demands the modern pharmaceutical analysis to develop rapid, reliable, selective and sensitive analytical methods for the determination of active ingredients and excipients in pharmaceuticals (David \& Webb, 2003).

Nowadays, by the reason of the accelerated pace of life, hyponutrition, people are exposed by a lacking of essential trace elements, among which the most common is iron deficiency. Iron is of vital importance in numerous biological processes, primarily involved oxygen binding and transport, muscle oxygen use and storage, gene regulation, cell growth and differentiation, enzyme reactions, neurotransmitter synthesis, and protein synthesis (Beard, 2001; Crichton, Wilmet, Legssyer, \& Ward, 2001; Halliberg, 2001; Schumann, Ettle, Szegner, Elsenhans, \& Sololmons, 2007). The lack of this element in the human body causes a widespread

\footnotetext{
* Corresponding author. Tel.: + 7929110 0987; fax: + 78123724421.

E-mail address: kristina-fulmes@mail.ru (C. Vakh).
}

disease - iron-deficiency anemia (IDA) (Clark, 2008). The treatment of IDA is provided by the antianemic drugs which contain iron (II) compounds and ascorbic acid as the mostly used excipient, which improves the gastrointestinal absorption of iron (Killip, Bennett, \& Chambers, 2007). However, such pharmaceuticals often cause side effects: nausea, anorexia, diarrhea and metal taste in the mouth (Beutler, Hoffbrand, \& Cook, 2003). Thus, it is important to carry out the quality control of antianemic drugs and determine the concentrations of iron (II) and ascorbic acid.

Traditionally, most methods of pharmaceutical analysis for separate determination of iron (II) and ascorbic acid are focused on the spectrophotometry (Davies \& Masten, 1991; Guclu, Sozgen, Tutem, Ozyurek, \& Apak, 2005; Karpinska \& Kulikowska, 2002; Zargba \& Hopkata, 1996) and electrochemistry (Mahmoud, 2001; Mary Nancy, Anithakumary, \& Kumara Swamy, 2014; Merli, Profumo, \& Dossi, 2012; Thangamuthu, Senthil Kumar, \& Chandrasekara Pillai, 2007) (Table 1). These methods are characterized by high selectivity, sensitivity, rapidity and the possibility of automation. However, these techniques as well as atomic absorption and emission spectrometry (Zachariadis \& Michos, 2007; Zachariadis, Raidou, Themelis, \& Stratis, 2002) are primarily focused on the determination of iron. In turn, the chromatography (Gioia, Andreatta, Boschetti, \& Gatti, 2008; Khuhawar \& Lanjwani, 1998; Pengfei et al., 2012) and the capillary electrophoresis (Fotsing, Fillet, Bechet, Hubert, \& Crommen, 1997; Lin Ling, Baeyens, Van Acker, \& Dewaele, 1992) are focused on the determination of iron (II) or ascorbic acid.

Inevitably, automation plays an important role in pharmaceutical analysis, especially when a lot of samples have to be analyzed in the 
Table 1

Reported methods for determination of iron (II) and ascorbic acid in pharmaceuticals.

\begin{tabular}{|c|c|c|c|c|c|c|c|c|}
\hline Method of analysis & Analyte & Detection & Matrix & $\begin{array}{l}\text { Linear range, } \\
\mathrm{mg} \mathrm{L}^{-1}\end{array}$ & $\begin{array}{l}\text { LOD, } \\
\mathrm{mg} \mathrm{L}^{-1}\end{array}$ & $\begin{array}{l}\text { Sample } \\
\text { frequency } \\
\left(\mathrm{h}^{-1}\right)\end{array}$ & $\begin{array}{l}\text { R.S.D., } \\
\%\end{array}$ & Reference \\
\hline \multirow[t]{6}{*}{ Spectrophotometry } & \multirow[t]{4}{*}{ Iron (II) } & $\begin{array}{l}\text { With 4-(2-pyridylazo) resorcinol at } \lambda=537 \mathrm{~nm} \text {, } \\
\mathrm{pH}=9.1 \text { (borate buffer) }\end{array}$ & Tablets & $0.025-0.2$ & 0.008 & 10 & 2.2 & $\begin{array}{l}\text { Karpinska \& } \\
\text { Kulikowska } \\
(2002)\end{array}$ \\
\hline & & \multirow{3}{*}{$\begin{array}{l}\text { With three azoderivatives of pyrocatechol at } \\
\lambda=490 ; 560 ; 600 \mathrm{~nm}, \mathrm{pH}=10.0\end{array}$} & \multirow[t]{3}{*}{ Tablets } & $0.05-2.11$ & 0.01 & \multirow[t]{3}{*}{10} & 3.0 & Zargba \& \\
\hline & & & & $0.05-0.89$ & 0.01 & & 2.7 & Hopkata (1996) \\
\hline & & & & $0.05-1.00$ & 0.01 & & 1.9 & \\
\hline & \multirow[t]{2}{*}{ Ascorbic acid } & With neocuproine at $\lambda=450 \mathrm{~nm}, \mathrm{pH}=7.0$ & Tablets & $1-15$ & 0.3 & 10 & 2.0 & $\begin{array}{l}\text { Guclu et al. } \\
\text { (2005) }\end{array}$ \\
\hline & & $\begin{array}{l}\text { With sodium 2,6-dichlorophenolindophenol at } \\
\lambda=520 \mathrm{~nm}, \mathrm{pH}=4.2\end{array}$ & Tablets & $0.3-20$ & 0.08 & 10 & 1.8 & $\begin{array}{l}\text { Davies \& } \\
\text { Masten (1991) }\end{array}$ \\
\hline \multirow[t]{4}{*}{$\begin{array}{l}\text { Electrochemical } \\
\text { methods }\end{array}$} & \multirow[t]{2}{*}{ Iron (II) } & Differential pulse voltammetry, $\mathrm{pH}=7.0$ & Tablets & $0.05-5$ & 0.017 & $5-10$ & 3.6 & $\begin{array}{l}\text { Merli et al. } \\
(2012)\end{array}$ \\
\hline & & $\begin{array}{l}\text { Potentiometric detection with ion-selective } \\
\text { electrode, } \mathrm{pH}=7.0\end{array}$ & Tablets & $0.028-560$ & 0.006 & $5-10$ & 2.6 & $\begin{array}{l}\text { Mahmoud } \\
(2001)\end{array}$ \\
\hline & \multirow[t]{2}{*}{ Ascorbic acid } & $\begin{array}{l}\text { Amperometric detection using glassy carbon } \\
\text { electrode modified by } \mathrm{K}_{4} \mathrm{Mo}(\mathrm{CN})_{8}, \mathrm{pH}=7.0\end{array}$ & Tablets & $2-100$ & 0.5 & $5-10$ & 3.5 & $\begin{array}{l}\text { Thangamuthu } \\
\text { et al. (2007) }\end{array}$ \\
\hline & & $\begin{array}{l}\text { Differential pulse voltammetry with glassy carbon } \\
\text { electrode modified by graphene, } \mathrm{pH}=7.0\end{array}$ & Tablets & $8-80$ & 0.7 & $5-10$ & 3.0 & $\begin{array}{l}\text { Mary Nancy } \\
\text { et al. (2014) }\end{array}$ \\
\hline \multirow[t]{2}{*}{ AAS/AES } & \multirow[t]{2}{*}{ Iron (II) } & AES with inductively coupled plasma & Tablets & $0.01-0.5$ & 0.002 & 10 & 2.3 & $\begin{array}{l}\text { Zachariadis \& } \\
\text { Michos (2007) }\end{array}$ \\
\hline & & AAS with flame atomization (air-acetylene flame) & Tablets & $0.5-4$ & 0.15 & $10-20$ & 1.1 & $\begin{array}{l}\text { Zachariadis } \\
\text { et al. (2002) }\end{array}$ \\
\hline \multirow[t]{3}{*}{ Chromatography } & Iron (II) & $\begin{array}{l}\text { Preliminary derivatization HPLC complexing agent } \\
\text { (2-thiophene aldehyde-4-phenyl-3-tiosemicarbazone), } \\
\text { stationary phase - C-18; mobile phase - a mixture of } \\
\text { methanol, acetonitrile, water, sodium acetate and } \\
\text { ammonium tetra butylbromide (78:10:10:1:1) }\end{array}$ & Tablets & $0.5-2.5$ & 0.025 & 4 & 4.8 & $\begin{array}{l}\text { Khuhawar \& } \\
\text { Lanjwani } \\
\text { (1998) }\end{array}$ \\
\hline & \multirow[t]{2}{*}{ Ascorbic acid } & $\begin{array}{l}\text { HPLC stationary phase }-C-18 \text {; mobile phase }-a \\
\text { mixture of phosphate buffer and acetonitrile }(95: 5)\end{array}$ & Tablets & $0.4-1.2$ & 0.13 & 10 & 2.0 & $\begin{array}{l}\text { Pengfei et al. } \\
(2012)\end{array}$ \\
\hline & & $\begin{array}{l}\text { Couple-ion reversed liquid chromatography; } \\
\text { stationary phase }-\mathrm{C}-18 \text {, mobile phase - } \\
\text { cetyltrimethylammonium bromide solution }\end{array}$ & $\begin{array}{l}\text { Injection } \\
\text { solutions }\end{array}$ & $14-45$ & 2 & 10 & 1.8 & $\begin{array}{l}\text { Gioia et al. } \\
(2008)\end{array}$ \\
\hline \multirow[t]{2}{*}{$\begin{array}{l}\text { Capillary } \\
\text { Electrophoresis }\end{array}$} & \multirow[t]{2}{*}{ Ascorbic acid } & $\begin{array}{l}\text { Detection in the medium of a borate buffer solution } \\
(\mathrm{pH}=8.5)\end{array}$ & Tablets & $0.2-1$ & 0.02 & 6 & 4.3 & $\begin{array}{l}\text { Fotsing et al. } \\
(1997)\end{array}$ \\
\hline & & $\begin{array}{l}\text { Detection in the medium of a phosphate buffer } \\
\text { solution }(\mathrm{pH}=5.0)\end{array}$ & Tablets & $10-1000$ & 0.5 & 12 & 5.0 & $\begin{array}{l}\text { Lin Ling et al. } \\
(1992)\end{array}$ \\
\hline \multirow[t]{9}{*}{ Flow analysis } & \multirow[t]{4}{*}{ Iron (II) } & FIA, reagent - salicylic acid, $\lambda=520 \mathrm{~nm}, \mathrm{pH}=4.0$ & Tablets & $1-20$ & 0.3 & 100 & 3.4 & $\begin{array}{l}\text { Udnana et al. } \\
(2004)\end{array}$ \\
\hline & & \multirow{3}{*}{$\begin{array}{l}\text { SIA, reagent }-1,10 \text {-phenanthroline, } \lambda=510 \mathrm{~nm} \text {, } \\
\mathrm{pH}=5.5 \\
\text { SIA, reagent }-2,2 \text {-bipyridyl, } \lambda=523 \mathrm{~nm}, \mathrm{pH}=4.5\end{array}$} & & $0.25-5$ & 0.02 & 40 & 3.0 & Tesfaldet et al. \\
\hline & & & Tablets & $5.0-40$ & 1.0 & 100 & 5.0 & $(2004)$ \\
\hline & & & & & & & & $\begin{array}{l}\text { Oliveira \& } \\
\text { Masini (2001) }\end{array}$ \\
\hline & Ascorbic acid & FIA, reagent - ferrozine, $\lambda=562 \mathrm{~nm}, \mathrm{pH}=5.5$ & Tablets & $0.1-20$ & 0.005 & 90 & 1.9 & $\begin{array}{l}\text { (Molina-Diaz } \\
\text { et al., 1998) }\end{array}$ \\
\hline & & $\begin{array}{l}\text { FIA, reagent }- \text { tripiridilttriazin iron (III), } \lambda=593 \\
\mathrm{~nm}, \mathrm{pH}=3.6\end{array}$ & Tablets & $0.015-2$ & 0.005 & 180 & 0.8 & $\begin{array}{l}\text { Kukoc-Modun } \\
\text { et al. (2012) }\end{array}$ \\
\hline & & SIA, reagent $-\mathrm{KMnO}_{4}, \lambda=525 \mathrm{~nm}$ & Tablets & $0.1-1000$ & 0.03 & 60 & 2.0 & $\begin{array}{l}\text { Lenghor et al. } \\
\text { (2002) }\end{array}$ \\
\hline & Iron (II) and Ascorbic & Flow sandwich technique, reagent for Iron (II) - & Tablets & $0.5-4$ & 0.2 & 41 & 3.0 & This \\
\hline & acid simultaneously & $\begin{array}{l}\text { 1,10-phenanthroline, } \lambda=510 \mathrm{~nm}, \mathrm{pH}=5.5 \\
\text { reagent for Ascorbic acid - sodium } \\
\text { 2,6-dichlorophenolindophenol, } \lambda=512 \mathrm{~nm}, \mathrm{pH}=4.5\end{array}$ & & $2-20$ & 0.7 & & 3.0 & work \\
\hline
\end{tabular}

minimum of time. The most widespread in pharmaceutical analysis are the flow injection (FIA) (Ruzicka \& Hansen, 1975) and sequential injection (SIA) analysis (Ruzicka \& Marshall, 1990). Coupling to FIA and SIA manifolds selective detectors make the developed approaches simple and easy implemented in pharmaceutical analysis (Horstkotte \& Cerdà, 2009; Mervartova, Polasek, \& Martınez Calatayud, 2007). Thus, flow analysis with spectrophotometric detection offers practically endless possibilities to the automation of pharmaceutical analysis procedures. Moreover it also provides miniaturization of analysis (Tzanavaras \& Themelis, 2007).

For the determination of iron (II) and ascorbic acid in pharmaceuticals the flow injection (Alonso, Bartrolí, del Valle, \& Barber, 1989; Alonso, Bartroli, Delvalle, Escalada, \& Barber, 1987; Alonso-Chamarro, Bartroli, \& Barber, 1992; Araujo, Lima, Alonso-Chamarro, Bartroli, \& Poch, 1991; Cerda \& Cerda, 2009; Falkova, Pushina, Bulatov, Alekseeva, \& Moskvin, 2014; Horstkotte \& Cerdà, 2009; ISO 5725-1, 1994; IUPAC, 1997;
Kukoc-Modun, Biocic, \& Radic, 2012; Lenghor et al., 2002; Mervartova et al., 2007; Molina-Diaz, Ortega-Carmona, \& Pascual-Reguera, 1998; Mortatti, Krug, Pessenda, \& Zagatto, 1982; Ruzicka \& Hansen, 1975; Ruzicka \& Marshall, 1990; Tzanavaras \& Themelis, 2007; Udnana et al., 2004) and sequential injection (Lenghor et al., 2002; Oliveira \& Masini, 2001; Tesfaldet, van Staden, \& Stefan, 2004) techniques were developed, which provide high sensitivity (Table 1 ) in combination with high sampling frequency (up to $180 \mathrm{~h}^{-1}$ ). However, they are focused only on the determination of iron (II) or ascorbic acid. To the best of our knowledge, simultaneous separate determination of iron (II) and ascorbic acid based on flow methods has not been reported.

This present work describes a new automated procedure for simultaneous separate determination of iron (II) and ascorbic acid in pharmaceuticals. For this purpose the flow system based on sandwich technique is implemented. At first the application of this technique in flow analysis was presented by Alonso and co-authors and was applied 
for the determination of iron (II) and total iron in a ground water samples (Alonso et al., 1989). The sandwich technique provides the strict order of reagents and sample injection into the flow system and means the sample "sandwiching" between two selective reagents (Alonso et al., 1987; Alonso-Chamarro et al., 1992; Araujo et al., 1991). During the moving thought the reaction coil two analytical products are formed. Despite the necessity to use the relatively large sample volume for preventing the overlapping of the colored zones, the sandwich technique is characterized by satisfactory sampling frequency because of the high flow rate using. Moreover, because of the optimizing of physical parameters of the flow systems it become possible to achieve the excellent repeatability of analysis and considerable reagent saving (Cerda \& Cerda, 2009).

\section{Materials and methods}

\subsection{Reagents and solutions}

All chemicals were of analytical reagent grade. Ultra pure water from Millipore Milli-Q RG (Millipore, USA) was used throughout the experiment. The stock solution of $0.045 \mathrm{M}$ of iron (II) was prepared by dissolving of the corresponding weight of $\mathrm{FeSO}_{4} \cdot\left(\mathrm{NH}_{4}\right)_{2} \mathrm{SO}_{4} \cdot 6 \mathrm{H}_{2} \mathrm{O}$ in $0.1 \mathrm{M} \mathrm{H}_{2} \mathrm{SO}_{4}$. The stock solution of $0.1 \mathrm{M}$ of ascorbic acid was prepared by dissolving of the corresponding weight in the water. The working solutions of analytes were prepared by appropriate dilution of the stock solutions with the water. The solution of $1 \mu \mathrm{M} 1,10$-phenanthroline and sodium 2,6-dichlorophenolindophenol were prepared by dissolving of the corresponding weights of reagents in the acetate buffer solution $(\mathrm{pH}=4.5)$ and the water, respectively. The 1,10-phenanthroline solution was colorless, stable within a week when stored in the dark place. The solution of sodium 2,6-dichlorophenolindophenol was brightly colored, stable within a week when stored at temperature from 2 to $5{ }^{\circ} \mathrm{C}$. The working solutions of reagents were prepared by appropriate dilution of the stock solutions with acetate buffer solution.

\subsection{Manifold and apparatus}

The flow system based on sandwich technique includes (Fig. 1): an eight-port valve (Cole-Parmer, USA), a peristaltic pump MasterFlex L/S (Cole-Parmer, USA) (flow rate $3.0 \mathrm{~mL} \mathrm{~min}^{-1}$ ), a reaction coil $(80 \mathrm{~cm}$ length and $1 \mathrm{~mm}$ in i.d.), home-made PTFE filter prepared according to Falkova et al. (2014) for filtering a sample solution and communication tubes (PTFE $1 \mathrm{~mm}$ in i.d.). It is equipped with a source of visible light
LS-1 and a USB 4000 spectrometer (Ocean Optics, USA) with a $50 \mathrm{~mm}$ path length flow cell FIA-Z-SMA-50-TEF (Fialab, USA). The analyzer was operated automatically by means a computer.

To carry out the reference analyses of pharmaceuticals a capillary electrophoresis system Capel-105M (Lumex, Russia) and an atomic absorption spectrometer AA-7000 (Shimadzu, Japan) were used. To carry out the sampling preparation of pharmaceuticals an ultrasonic bath Sapphire (Sapphire, Russia) was used.

\subsection{Samples}

Three different samples of antianemic drugs at solid dosage form "Sorbifer Durules", "Fenules" and "Tardyferon" were analyzed. All these antianemic drugs contain ferrous sulfate as active ingredient and ascorbic acid as excipient, with dosage form $500 \mathrm{mg}$.

\subsection{Sample preparation}

The sample preparation was performed by ultrasound-assisted dissolution of solid dosage form of antianemic drugs in the medium of $0.1 \mathrm{M} \mathrm{HCl}$. Three tablets of antianemic drugs were grounded to a homogeneous powder in a ceramic mortar. Then, $0.01 \mathrm{~g}$ of the powder was mixed with $1 \mathrm{~g}$ of potassium chloride. This step is carrying out because of the high content of iron (II) and ascorbic acid in antianemic drugs. Further, $0.01 \mathrm{~g}$ of the obtained mixture was placed in a glass vessel and the $5 \mathrm{~mL}$ of $0.1 \mathrm{M} \mathrm{HCl}$ was added. Afterwards the dissolution of antianemic drugs took place under ultrasonication $(325 \mathrm{~W}, 35 \mathrm{kHz})$ at $20{ }^{\circ} \mathrm{C}$ for $10 \mathrm{~min}$. The prepared solution was then analyzed by flow system based on sandwich technique. While the calculation of the content of the iron (II) and ascorbic acid in the tablet, the mass of the tablet and the analyte content using the calibration curve were taken into consideration.

\subsection{The procedure of flow determination of iron (II) and ascorbic acid}

To implement the flow system based on sandwich technique (Fig. 1) the portions of sample and reagent solutions were sequentially delivered into the reaction coil by movement of the peristaltic pump through a eight-port valve in strict order: $75 \mu \mathrm{L}$ of acetate buffer solution as the carrier solution $(g), 150 \mu \mathrm{L}$ of 1,10-phenanthroline solution (b), $1 \mathrm{~mL}$ of sample solution (a), $150 \mu \mathrm{L}$ of sodium 2,6-dichlorophenolindophenol solution $(d)$ and again $500 \mu \mathrm{L}$ of carrier solution $(g)$. The high flow rate $\left(3.0 \mathrm{~mL} \mathrm{~min}^{-1}\right)$ and a large volume of the sample eliminate overlapping

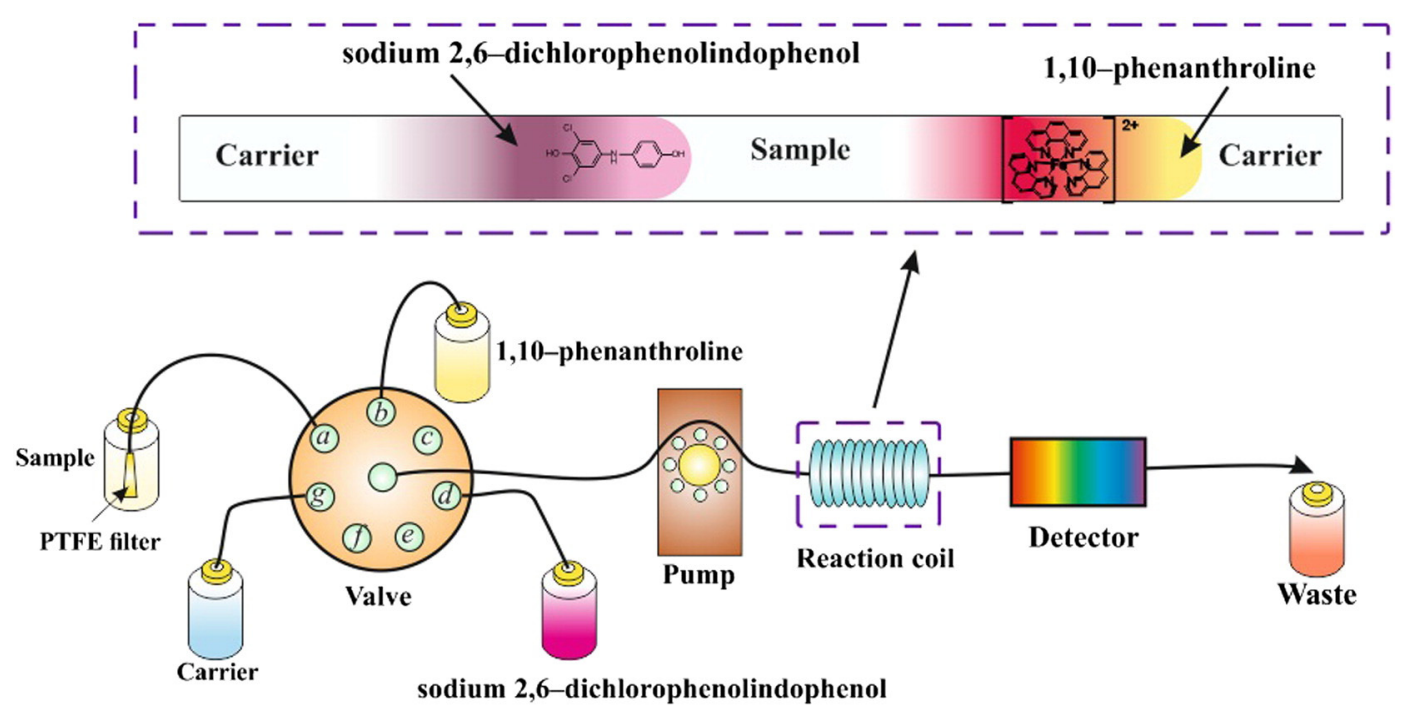

Fig. 1. The manifold of the flow system based on sandwich technique. 
of the colored zones of reaction products. The analytical signals were measured in the flow-stop condition for $3 \mathrm{~s}$ by means of the spectrophotometer at the wavelength $510 \mathrm{~nm}$ for iron (II) and $512 \mathrm{~nm}$ for ascorbic acid. The first analytical signal corresponds the complex of iron (II) with 1,10-phenanthroline, the second one - the product of ascorbic acid with sodium 2,6-dichlorophenolindophenol. To avoid the memory effect the manifold was washed out with carrier solution. To ensure the strict order of zones formation, sequence and time of performing of all analysis steps the special program was set up.

\subsection{Procedure for the determination of iron (II) and ascorbic acid by reference methods}

For the AAS determination of iron (II) in antianemic drugs the pretreatment stage was performed by ultrasound-assisted dissolution of powdered tablets in $50 \mathrm{~mL}$ of $1 \mathrm{M} \mathrm{HNO}_{3}$ for $10 \mathrm{~min}$. Then, the mixture was filtered through the paper filter and farther analyzed by AAS with atomization in a continuous flame.

For the CE determination of ascorbic acid in antianemic drugs the pre-treatment stage was performed by ultrasound-assisted dissolution of powdered tablets in $5 \mathrm{~mL}$ of $0.1 \mathrm{M} \mathrm{HCl}$ for $10 \mathrm{~min}$. For the stabilization of ascorbic acid in the prepared solution $10 \mathrm{~mL}$ of $0.05 \mathrm{M}$ EDTA was added. Then, the mixture was filtered through the paper filter and farther analyzed by capillary electrophoresis. The length of used quartz capillary was $50 \mathrm{~cm}$ with $75 \mu \mathrm{m}$ in i.d. The measurements were performed at $254 \mathrm{~nm}$ using $\mathrm{Na}_{2} \mathrm{~B}_{4} \mathrm{O}_{7}$ - sodium dodecyl sulfate solution as a supporting electrolyte.

\section{Results and discussion}

\subsection{Theoretical aspects}

For the spectrophotometric determination of iron (II) a well-known color-forming reagent 1,10-phenanthroline was used. This reaction proceeds in wide range of $\mathrm{pH}$ from 2.0 to 9.0 in a molar ratio 3:1 $\left(\mathrm{R}_{\mathrm{Fe}}{ }^{2+}\right)$ (Mortatti et al., 1982). The complex absorbance maxima is observed at the $510 \mathrm{~nm}\left(\varepsilon_{510}=1.1 \times 10^{4} \mathrm{~L} \mathrm{~mol}^{-1} \mathrm{~cm}^{-1}\right)$.

For the spectrophotometric determination of ascorbic acid the reagent sodium 2,6-dichlorophenolindophenol was chosen, because of the reducing properties of the analyte. This reaction proceeds in a molar ratio 1:1 according to the following schematic representation:

In the acidic medium the reagent solution has a purple color, which is discoloring during the interaction with ascorbic acid. Absorbance maximum of sodium 2,6-dichlorophenolindophenol is observed at the $512 \mathrm{~nm}\left(\varepsilon_{512}=3.2 \times 10^{4} \mathrm{~L} \mathrm{~mol}^{-1} \mathrm{~cm}^{-1}\right)$.

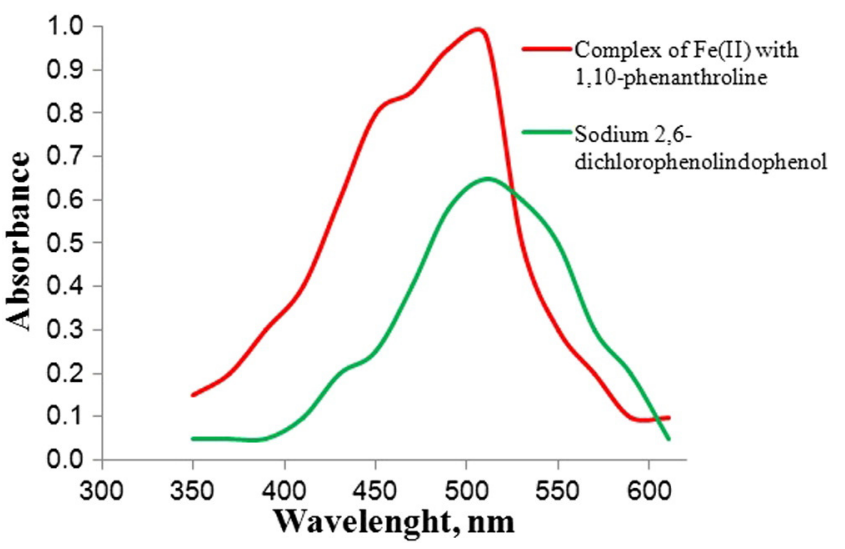

Fig. 2. Absorbance spectra of complex of Fe (II) with 1,10-phenanthroline $\left(C_{R}=10^{-4} \mathrm{M}\right.$, $\left.\mathrm{CFe}^{2+}=10^{-4} \mathrm{M}, \mathrm{pH}=4.5\right)$ and sodium 2,6-dichlorophenolindophenol $\left(\mathrm{C}_{\mathrm{R}}=10^{-4} \mathrm{M}\right.$, ascorbic acid $=10^{-4} \mathrm{M}, \mathrm{pH}=4.5$ ).
The absorbance spectra of complex of Fe (II) with 1,10phenanthroline and sodium 2,6-dichlorophenolindophenol are presented in the Fig. 2 .

The reaction between ascorbic acid and sodium 2,6dichlorophenolindophenol is strongly dependent on the acidity of the medium. However, solving the problem of choosing the optimal $\mathrm{pH}$ of the reaction, it was necessary to take into account the presence of iron (II) in the antianemic drugs and its possible influence on the reaction. According to Davies \& Masten (1991), it was decided to carry out the reaction in the presence of acetate buffer solution. In the $\mathrm{pH}$ range from 4.0 to 4.5 the interference effect of $\mathrm{Fe}^{2+}$ ions is not found. Thus, the acetate buffer solution ( $\mathrm{pH}=4.5$ ) was used as an appropriate carrier-solution.

\subsection{Optimization of parameters}

The conditions for the determination of iron (II) and ascorbic acid were optimized by studying the influence of the various parameters such as flow rate, sample and reagent volumes, reaction coil length and reagent concentration. $4 \times 10^{-5} \mathrm{M}$ of iron (II) and ascorbic acid, $5 \times 10^{-3} \mathrm{M}$ of 1,10 -phenanthroline and $5 \times 10^{-4} \mathrm{M}$ of sodium 2,6dichlorophenolindophenol were used to optimize these parameters. In all cases both the relative peak height and percentage of RSD were used as criteria for establishing the most appropriate parameters.

The flow rate is a very important parameter to be optimized because it influences to the products formation. The reactions between iron (II) and 1,10-phenanthroline as well as ascorbic acid and sodium 2,6dichlorophenolindophenol are rapid, resulting in an almost instant products formation. The flow rate was varied between 0.5 and

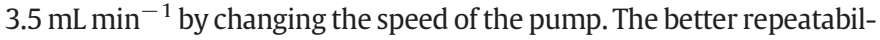
ity and lower consumption of carrier-solution was achieved at $3.0 \mathrm{~mL} \mathrm{~min}^{-1}$ and this flow rate was chosen as optimum working condition (Fig. 3A).

The aim of optimization of sample and reagent volumes is to minimize the consumption of sample and reagents, maintaining the best sensitivity and repeatability and to prevent the mixing of products while moving them in the reaction coil into the detector. The injected sample volume was varied from 0.5 to $1.5 \mathrm{~mL}$ and the volumes of 1,10-phenanthroline and sodium 2,6-dichlorophenolindophenol were varied from 50 to $250 \mu \mathrm{L}$. The results presented in the Fig. 3B shown that the injected sample volume less than $1 \mathrm{~mL}$ leads to decreasing of repeatability because product zone mixing is observed. It was also found that optimal reagent volumes are $150 \mu \mathrm{L}$ for both reagents (Fig. 3C).

The reaction coil is usually kept as short as possible to avoid the product dispersion but sufficient to provide the product formation. The length of this coil was varied from 50 to $100 \mathrm{~cm}$. The optimum length of the reaction coil was $80 \mathrm{~cm}$, which ensures the effective overlapping zones of reagents with the sample and prevent the mixing of products zones (Fig. 3D).

The concentrations of the reagents were varied from $1 \times 10^{-3}$ to $1 \times 10^{-2} \mathrm{M}$ of 1,10 -phenanthroline and from $1 \times 10^{-4}$ to $1 \times 10^{-3} \mathrm{M}$ of sodium 2,6-dichlorophenolindophenol. It was found that the optimal concentrations of 1,10-phenanthroline and sodium 2,6dichlorophenolindophenol are $5 \times 10^{-3}$ and $5 \times 10^{-4} \mathrm{M}$, respectively.

\subsection{Optimization of dissolution}

Most of antianemic drugs are in a solid dosage form with a relatively high content of iron (II) and ascorbic acid (13-20\%). Therefore, it is important to provide the effective dissolution as well as dilution of the sample. It is known that $\mathrm{H}_{2} \mathrm{SO}_{4}$ and $\mathrm{HNO}_{3}$ have strong oxidizing properties, which contribute to the destruction of ascorbic acid and oxidation of $\mathrm{Fe}^{2+}$ to $\mathrm{Fe}^{3+}$. Thus for investigating of the sample dissolution the deionized water and $\mathrm{HCl}$ were used. The effects of temperature, thermostating and ultrasonication time were investigated to increase 

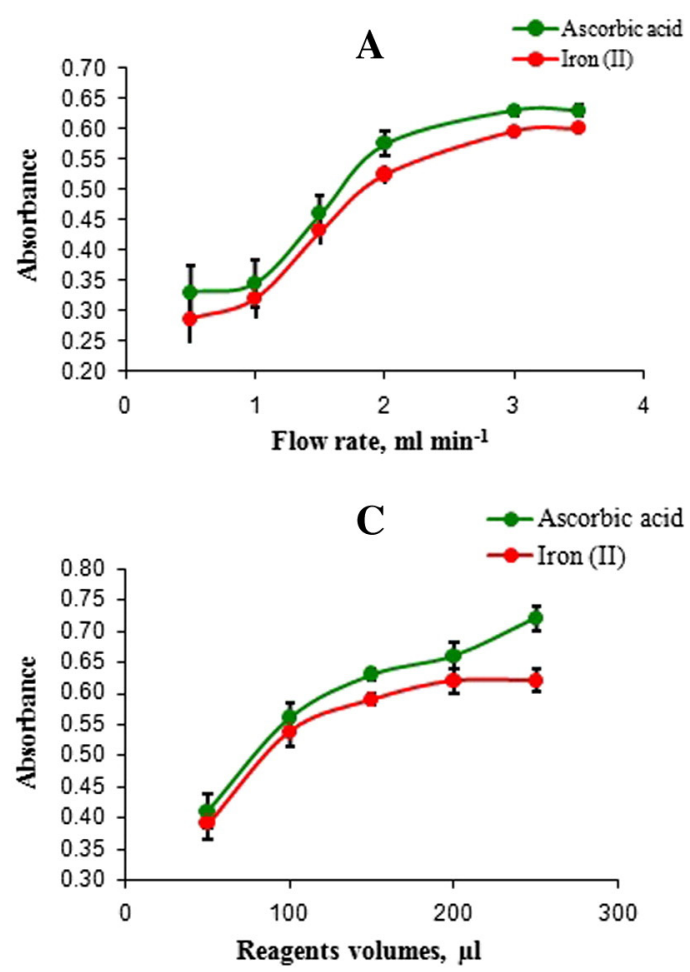
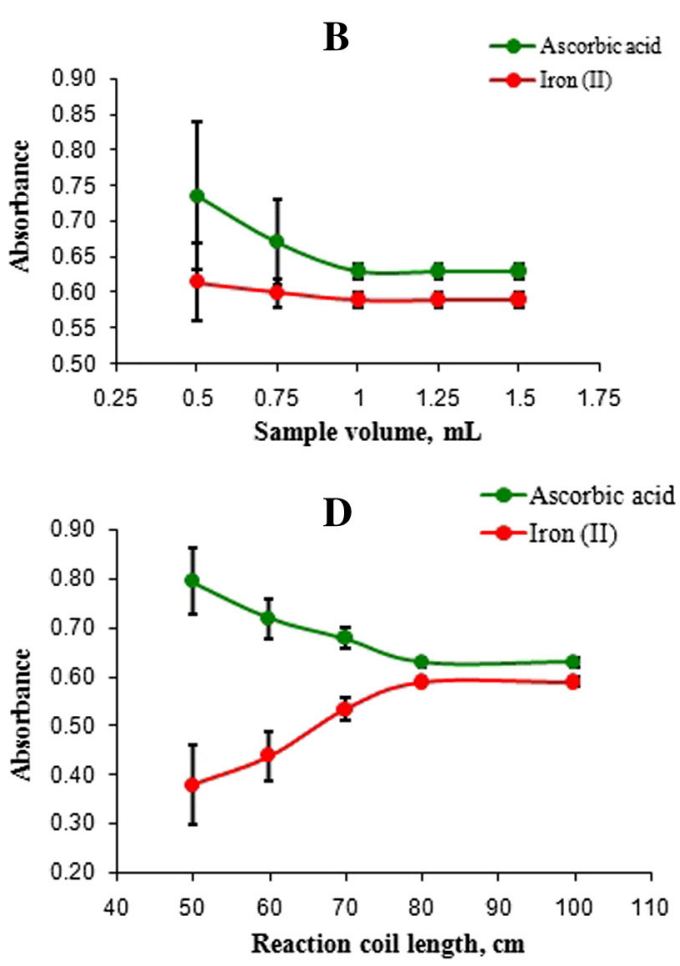

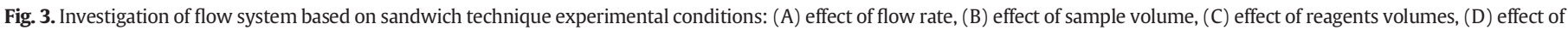
reaction coli length.

the efficiency of dissolution. Thus the temperature was varied from 20 to $50{ }^{\circ} \mathrm{C}$ and the thermostating and ultrasonication time - from 2 to $20 \mathrm{~min}$. Two parallel experiments were performed - with and without ultrasound assistants. The results showed that effective dissolution of antianemic drugs is observed in the media of $0.1 \mathrm{M} \mathrm{HCl}$ at $50{ }^{\circ} \mathrm{C}$ for 10 min without ultrasonication and at $20{ }^{\circ} \mathrm{C}$ for 10 min with ultrasonication.

\subsection{Interference effect}

The effect of potentially interfering components presented in antianemic drugs $\left(\mathrm{Mg}^{2+}, \mathrm{Co}^{2+}, \mathrm{Cu}^{2+}, \mathrm{SO}_{4}^{2-}\right.$ ions and riboflavin, pyridoxine, thiamine and pantothenic acid) on the determination of analytes was investigated. It was performed by addition of known concentration of each component into a model solution, containing iron (II) ions and ascorbic acid at concentration of $4 \times 10^{-5} \mathrm{M}$ in $0.1 \mathrm{M}$ hydrochloric acid. The tolerable excess of each taken foreign species is considered to be less than $5 \%$ of relative error in the signal. The greatest influence (less than 10-fold excess) on the product formation has riboflavin, thiamine, pyridoxine and pantothenic acid, but in the antianemic drugs a content of these components is much lower than the content of iron (II) and ascorbic acid. Thus it should be concluded with the absence of interference effect.

\subsection{Validation}

For validation, the following parameters were evaluated for linearity and sensitivity, precision, recoveries and accuracy.

\subsubsection{Linearity and sensitivity}

Under the optimized reaction condition according to the previously described procedure, the calibration curves for iron (II) and ascorbic acid determination were constructed from ten data points using the standard solution of analytes (Fig. 4). The relationship obtained between the relative peak height and concentrations of iron (II) as well as ascorbic acid were given by the follow equations:

$$
\begin{aligned}
\text { Relative peak height }= & 0.231 \times\left[\text { Concentration of Fe }(\mathrm{II}), \mathrm{mg} \mathrm{L}^{-1}\right] \\
& +0.062, r^{2}=0.996 ; \\
\text { Relative peak height }= & -0.046 \times\left[\text { Concentration of ascorbic acid }(\mathrm{II}), \mathrm{mg} \mathrm{L}^{-1}\right] \\
& +0.0968, r^{2}=0.995 .
\end{aligned}
$$

The absorbance of colored products at the wavelength $510 \mathrm{~nm}$ and $512 \mathrm{~nm}$ for iron (II) and ascorbic acid, respectively, obey the Beer's law in the range of $0.5-4.0 \mathrm{mg} \mathrm{L}^{-1}$ for iron (II) and of $2.0-20 \mathrm{mg} \mathrm{L}^{-1}$ for ascorbic acid.

The sensitivity was characterized by the limit of detection (LOD). It was measured by standard IUPAC method as 3 standard deviation of the blank (3 s) (IUPAC, 1997). The LODs calculated from the calibration plots based on $3 \mathrm{~s}$ were $0.2 \mathrm{mg} \mathrm{L}^{-1}$ for iron (II) and $0.7 \mathrm{mg} \mathrm{L}^{-1}$ for ascorbic acid. The results indicated that the LODs both for iron (II) and ascorbic acid are satisfied for their determination in antianemic drugs.

\subsubsection{Precision}

The precision of the method was evaluated with regard to its repeatability and reproducibility (ISO 5725-1, 1994).

The repeatability of the developed approach was determined by analyzing 10 replicates of model solutions which contain iron (II) and ascorbic acid in the range from $0.5 \mathrm{mg} \mathrm{L}^{-1}$ to $4.0 \mathrm{mg} \mathrm{L}^{-1}$ and from $2 \mathrm{mg} \mathrm{L}^{-1}$ to $20 \mathrm{mg} \mathrm{L}^{-1}$, respectively. It was studied that the developed flow sandwich-type approach provides satisfactory results. The RSD values were $<3.0 \%$. This level of precision of the proposed flow sandwich-type approach was adequate for quality-control of antianemic drugs.

The reproducibility of the proposed methods was assessed by applying the developed flow sandwich-type approach with the use of 2 different instruments in 2 different laboratories at 2 different times. Results 

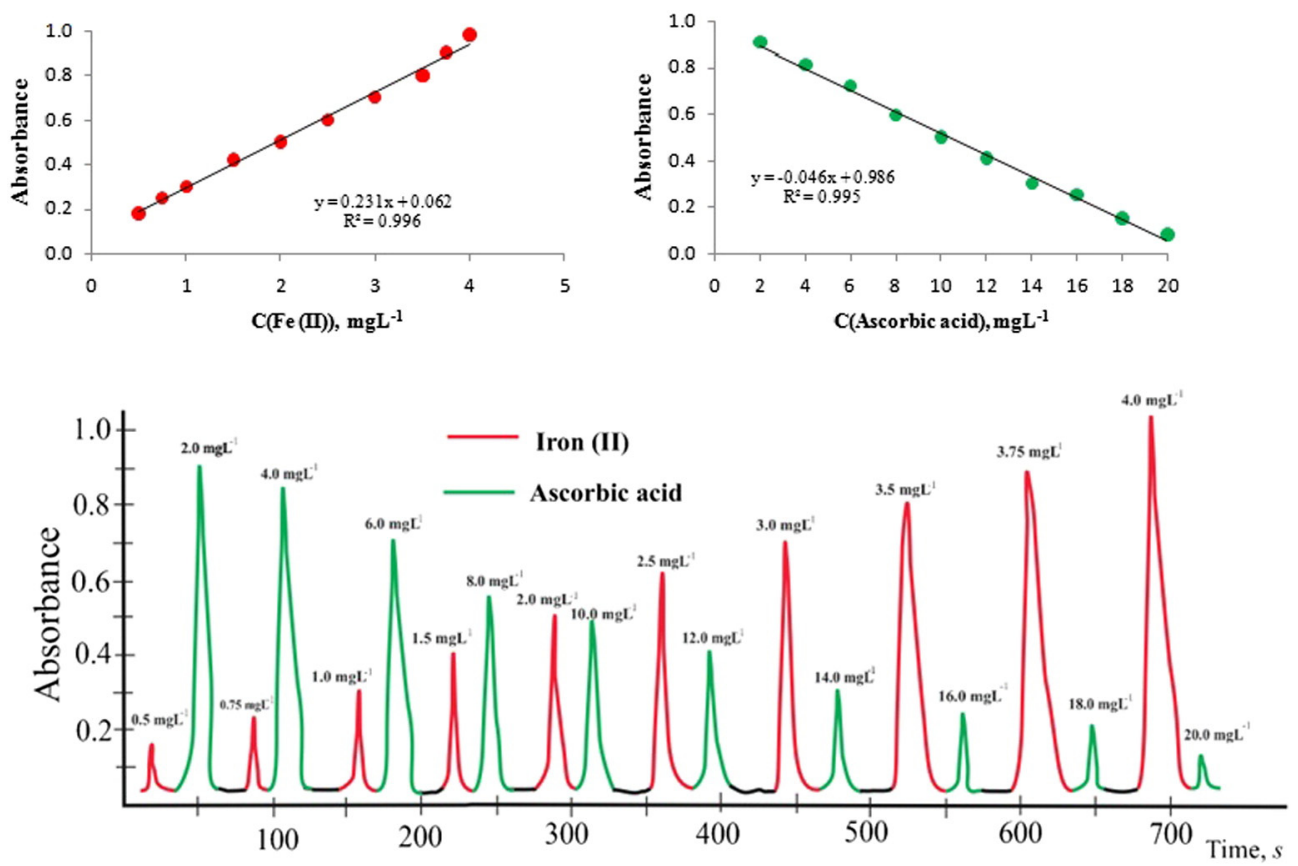

Fig. 4. Calibration curves and depiction of absorbance peaks obtained by suggested flow system based on sandwich technique.

obtained with the laboratory-to-laboratory and day-to-day variations were found to be reproducible because the RSD values under conditions were $5.0 \%$

\subsubsection{Recovery}

Recovery values were determined for each analyte at $2 \mathrm{mg}$ and $5 \mathrm{mg}$ concentrations in dosage form of antianemic drugs. The investigation was performed for 3 replicate of three samples ("Sorbifer Durules", "Fenules", "Tardyferon"). The standard additions of analytes were placed into the samples of antianemic drugs before dissolving. It is shown in Table 2 that recovery values for both analytes are between 98 and $102 \%$

\subsubsection{Accuracy}

The available solid dosage form of antianemic drugs was analyzed by proposed approach and by reference methods: AAS for iron determination and CE for ascorbic acid determination. It should be pointed out that in the presence of ascorbic acid iron exists in the form of Fe (II). The accuracy of the approach was evaluated by the comparison of the results receiving by both approaches. The obtained results represent no significant differences in iron (II) and ascorbic acid concentrations obtained by suggested and reference methods (Table 2). Student's $t$-test of statistical hypotheses about the equality of the means was used to test the equality of the means of the experimental data obtained by developed method and by the reference method. Hypothesis about the equality of the means of the experimental data obtained by the developed method and by the reference method was taken as the null hypothesis $\left(\mathrm{H}_{0}\right)$. Hypothesis about the difference of mentioned means was taken as an alternative hypothesis $\left(\mathrm{H}_{1}\right)$. The significance was taken equal to the 0.05 level. Based on the obtained results, the observed differences were not contrary to the hypothesis $\mathrm{H}_{0}$ and the obtained discrepancies with the 0.05 significance level could be considered insignificant.

\section{Conclusion}

In comparison with the previously reported flow approaches (Kukoc-Modun et al., 2012; Lenghor et al., 2002; Molina-Diaz et al., 1998; Oliveira \& Masini, 2001; Tesfaldet et al., 2004; Udnana et al., 2004 ) the flow system based on sandwich technique has been proposed for the simultaneous separate determination of iron (II) and ascorbic acid in antianemic pharmaceuticals for the first time. Taking into account high content of analytes (13-20\%) in the pharmaceuticals the LOD values of the developed approach are quite satisfactory. The sample frequency of the developed approach is comparable with the previously reported flow approaches, because during the one flow cycle it is

Table 2

The results of the iron (II) and ascorbic acid determination in antianemic pharmaceuticals (F-critical $=19.0, \mathrm{t}$-critical $=4.3, \mathrm{P}=0.95, \mathrm{n}=3$ )

\begin{tabular}{|c|c|c|c|c|c|c|c|c|c|c|c|c|c|}
\hline \multirow[t]{2}{*}{ Drug } & \multicolumn{2}{|c|}{$\begin{array}{l}\text { Labeled value, } \\
\text { mg/tablets }\end{array}$} & \multirow[t]{2}{*}{$\begin{array}{l}\text { Added } \\
\text { amount, } \\
\text { mg/tablets }\end{array}$} & \multirow{2}{*}{$\begin{array}{l}\text { The developed } \\
\text { method, } \\
\text { mg/tablets } \\
\text { Iron (II) }\end{array}$} & \multirow[t]{2}{*}{ AAS, mg/tablets } & \multirow[t]{2}{*}{ F-value } & \multirow[t]{2}{*}{ t-value } & \multirow[t]{2}{*}{$\begin{array}{l}\text { Recovery, } \\
\%\end{array}$} & \multirow{2}{*}{$\begin{array}{l}\text { The developed } \\
\text { method, } \\
\text { mg/tablets } \\
\text { Ascorbic acid }\end{array}$} & \multirow[t]{2}{*}{ CE, mg/tablets } & \multirow[t]{2}{*}{ F-value } & \multirow[t]{2}{*}{ t-value } & \multirow[t]{2}{*}{$\begin{array}{l}\text { Recovery, } \\
\%\end{array}$} \\
\hline & $\mathrm{Fe}(\mathrm{II})$ & AA & & & & & & & & & & & \\
\hline \multirow[t]{3}{*}{ Sorbifer Durules } & 100 & 60 & 0 & $95 \pm 5$ & $96 \pm 8$ & 2.5 & 0.5 & - & $58 \pm 4$ & $57 \pm 2$ & 7.0 & 1.1 & - \\
\hline & & & 2 & $96 \pm 5$ & $97 \pm 7$ & 1.1 & 0.3 & 99 & $61 \pm 5$ & $60 \pm 6$ & 1.6 & 0.7 & 101 \\
\hline & & & 5 & $101 \pm 5$ & $100 \pm 8$ & 2.3 & 0.5 & 101 & $63 \pm 5$ & $62 \pm 5$ & 1.7 & 0.5 & 101 \\
\hline \multirow[t]{3}{*}{ Fenules } & 55 & 50 & 0 & $58 \pm 3$ & $60 \pm 5$ & 4.3 & 1.8 & - & $66 \pm 5$ & $67 \pm 3$ & 5.2 & 0.5 & - \\
\hline & & & 2 & $61 \pm 4$ & $62 \pm 6$ & 2.7 & 0.6 & 98 & $69 \pm 4$ & $70 \pm 4$ & 1.0 & 0.8 & 99 \\
\hline & & & 5 & $64 \pm 5$ & $65 \pm 6$ & 1.3 & 0.8 & 99 & $72 \pm 5$ & $73 \pm 4$ & 4.0 & 0.8 & 99 \\
\hline \multirow[t]{3}{*}{ Tardyferon } & 80 & - & 0 & $69 \pm 4$ & $70 \pm 5$ & 1.9 & 0.7 & - & $86 \pm 4$ & $87 \pm 3$ & 1.8 & 0.3 & - \\
\hline & & & 2 & $72 \pm 4$ & $71 \pm 4$ & 0.7 & 0.5 & 101 & $88 \pm 4$ & $90 \pm 5$ & 1.3 & 1.3 & 102 \\
\hline & & & 5 & $74 \pm 5$ & $75 \pm 6$ & 1.6 & 0.4 & 99 & $91 \pm 4$ & $93 \pm 5$ & 1.7 & 1.1 & 98 \\
\hline
\end{tabular}


possible to analyzed two analytes. The proposed procedure is of great value in quality-control analysis of the developed pharmaceuticals, because it improves automation, miniaturization, simplicity, sensitivity, flexibility and low cost.

\section{Acknowledgments}

This work was supported by the Russian Foundation for Basic Research (project No. 13-03-00031-a). Scientific researches were performed at the Center for chemical analysis and materials research of St. Petersburg State University.

\section{References}

Alonso, J., Bartrolí, J., del Valle, M., \& Barber, R. (1989). Sandwich techniques in flowinjection analysis: Part 2. Simultaneous determination of Iron (II) and total Iron. Analytica Chimica Acta, 219, 345-350.

Alonso, J., Bartroli, J., Delvalle, M., Escalada, M., \& Barber, R. (1987). Sandwich techniques in flow injection analysis. Part 1. Continuous recalibration technique for process control. Analytica Chimica Acta, 199, 191-196.

Alonso-Chamarro, J., Bartroli, J., \& Barber, R. (1992). Sandwich techniques in flow injection analysis. Part3. Simultaneous determination of $\mathrm{Cr}(\mathrm{VI})$ in two concentration ranges. Analytica Chimica Acta, 261, 219-223.

Araujo, A. N., Lima, J. L. F. C., Alonso-Chamarro, J., Bartroli, J., \& Poch, M. (1991). Flow injection system based on the sandwich technique for saving expensive reagents. Clinica Chimica Acta, 203, 67-76.

Beard, J. L. (2001). Iron biology in immune function, muscle metabolism and neuronal functioning. The Journal of Nutrition, 131, 568-579.

Beutler, E., Hoffbrand, A. V., \& Cook, J. D. (2003). Iron deficiency and overload, hematology, The Educational Prog. American Society of Hematology, 40-61.

Cerda, A., \& Cerda, V. (2009). An introduction to flow analysis, SCIWARE, Palma de Mallorca, $66-67$.

Clark, S. F. (2008). Iron deficiency anemia. Nutrition in Clinical Practice, 23, 128-141.

Crichton, R. R., Wilmet, S., Legssyer, R., \& Ward, F. R. (2001). Molecular and cellular mechanisms of iron homeostasis and toxicity in mammalian cells. Journal of Inorganic Biochemistry, 91, 9-18.

David, C. L., \& Webb, L. M. (2003). Pharmaceutical analysis. Blackwell Publishing Ltd.

Davies, S. H. R., \& Masten, S. J. (1991). Spectrophotometric method for ascorbic acid using dichlorophenolindophenol: elimination of the interference due to iron. Analytica Chimica Acta, 248, 225-221.

Falkova, M. T., Pushina, M. O., Bulatov, A. V., Alekseeva, G. M., \& Moskvin, L. N. (2014). Stepwise injection spectrophotometric determination of flavonoids in medicinal plants. Analytical Letters, 47, 970-982.

Fotsing, L., Fillet, M., Bechet, I., Hubert, Ph., \& Crommen, J. (1997). Determination of six water-soluble vitamins in a pharmaceutical formulation by capillary electrophoresis. Journal of Pharmaceutical and Biomedical Analysis, 15, 1113-1123.

Gioia, M. G., Andreatta, P., Boschetti, S., \& Gatti, R. (2008). Development and validation of liquid chromatographic method for the determination of ascorbic acid, dehydroascorbic acid and acetaminophen in pharmaceuticals. Journal of Pharmaceutical and Biomedical Analysis, 48, 331-339.

Guclu, K., Sozgen, K., Tutem, E., Ozyurek, M., \& Apak, R. (2005). Spectrophotometric determination of ascorbic acid using copper (II) - neocuproine reagent in beverages and pharmaceuticals. Talanta, 65, 1226-1232.

Halliberg, L. (2001). Perspectives on nutritional iron deficiency. Annual Review of Nutrition, 21, 1-21.

Horstkotte, B., \& Cerdà, V. (2009). Coupling of flow techniques with capillary electrophoresis: review of operation principles, challenges, potentials, and applications. Journal of Chromatographic Science, 47, 636-647.

ISO 5725-1 (1994). Accuracy (trueness and precision) of measurement methods and results - Part 1: General principles and definitions.

IUPAC (1997). Compendium of chemical terminology The "Gold Book" (2nd ed.).

Jackson, K., Young, D., \& Pant, S. (2000). Drug-excipient interactions and their affect on absorption. Pharmaceutical Science E Technology, 3, 336-345.

Karpinska, J., \& Kulikowska, M. (2002). Simultaneous determination of zinc (II), manganese (II) and iron (II) in pharmaceutical preparations. Journal of Pharmaceutical and Biomedical Analysis, 29, 153-158.

Khuhawar, M. Y., \& Lanjwani, S. N. (1998). Liquid chromatographic determination of cobalt (II), copper (II) and iron (II) using 2-thiophenaldehyde-4-phenyl-3thiosemicarbazone as derivatizing reagent. Talanta, 46, 485-490.

Killip, S., Bennett, J. M., \& Chambers, M. D. (2007). Iron deficiency anemia. American Family Physician, 75, 671-678.
Kukoc-Modun, L, Biocic, M, \& Radic, N. (2012). Indirect method for spectrophotometric determination of ascorbic acid in pharmaceutical preparations with 2,4,6-tripyridyls-triazine by flow-injection analysis. Talanta, 96, 174-179.

Lenghor, N., Jakmunee, J., Vilen, M., Sara, R., Christian, G. D., \& Grudpan, K. (2002). Sequential injection redox or acid-base titration for determination of ascorbic acid or acetic acid. Talanta, 58, 1139-1144

Lin Ling, B., Baeyens, W. R. G., Van Acker, P., \& Dewaele, C. (1992). Determination of ascorbic acid and isoascorbic acid by capillary zone electrophoresis: application to fruit juices and to a pharmaceutical formulation. Journal of Pharmaceutical and Biomedical Analysis, 10, 717-721.

Mahmoud, W. H. (2001). Iron ion-selective electrodes for direct potentiometry and potentiotitrimetry in pharmaceuticals. Analytica Chimica Acta, 436, 199-206.

Mary Nancy, T. E., Anithakumary, V., \& Kumara Swamy, B. E. (2014). Solar graphene modified glassy carbon electrode for the voltammetric resolution and detection of dopamine, ascorbic acid and uric acid. Journal of Electroanalytical Chemistry, 720-721, 107-114.

Merli, D., Profumo, A., \& Dossi, C. (2012). An analytical method for Fe (II) and Fe (III) determination in pharmaceutical grade iron sucrose complex and sodium ferric gluconate complex. Journal of Pharmaceutical Analysis, 2, 450-453.

Mervartova, K., Polasek, M., \& Martınez Calatayud, J. (2007). Recent applications of flowinjection and sequential-injection analysis techniques to chemiluminescence determination of pharmaceuticals. Journal of Pharmaceutical and Biomedical Analysis, 45 , 367-381.

Molina-Diaz, A., Ortega-Carmona, I., \& Pascual-Reguera, M. I. (1998). Indirect spectrophotometric determination of ascorbic acid with ferrozine by flow-injection analysis. Talanta, 47, 531-536.

Mortatti, J., Krug, F. J., Pessenda, L. C. R., \& Zagatto, E. A. G. (1982). Determination of iron in natural waters and plant material with 1,10-phenanthroline by flow injection. Analyst, 107, 659-663.

Oliveira, P. C. C., \& Masini, J. C. (2001). Sequential injection of iron (II) in antianemic pharmaceutical formulations with spectrofotometric detection. Analytical Letters, 34 389-397.

Pengfei, J., Lufeng, X., Zheng, L., Ning, Ch., Ding, Z., \& Xin, H. (2012). Rapid determination of thiamine, riboflavin, niacinamide, pantothenic acid, pyridoxine, folic acid and ascorbic acid in vitamins with minerals tablets by high-performance liquid chromatography with diode array detector. Journal of Pharmaceutical and Biomedical Analysis, 70, 151-157.

Pifferi, G., \& Restani, P. (2003). The safety of pharmaceutical excipients II. Farmaco, 58 , 541-550.

Pimenta, A. M., Montenegro, M. C. B. S. M., Araujo, A. N., \& Martınez Calatayud, J. (2006) Review. Application of sequential injection analysis to pharmaceutical analysis. Journal of Pharmaceutical and Biomedical Analysis, 40, 16-34.

Ruzicka, J., \& Hansen, E. H. (1975). Flow injection analyses: Part I. A new concept of fast continuous flow analysis. Analytica Chimica Acta, 78, 145-157.

Ruzicka, J., \& Marshall, G. D. (1990). Sequential injection: A new concept for chemica sensors, process analysis and laboratory assays. Analytica Chimica Acta, 237, 329-343.

Schumann, K., Ettle, T., Szegner, B., Elsenhans, B., \& Sololmons, N. (2007). On risks and benefits of iron supplementation recommendations for iron intake revisited. Journal of Trace Elements in Medicine and Biology, 21, 147-168.

Tesfaldet, Z. O., van Staden, J. F. \& Stefan, R. I. (2004). Sequential injection spectrophotometric determination of iron as Fe (II) in multi-vitamin preparations using 1,10 phenanthroline as complexing agent. Talanta, 64, 1189-1195.

Thangamuthu, R., Senthil Kumar, S. M., \& Chandrasekara Pillai, K. (2007). Direct amperometric determination of L-ascorbic acid (Vitamin C) at octacyanomolybdate-dopedpoly(4-vinylpyridine) modified electrode in fruit juice and pharmaceuticals. Sensors and Actuators, B, 120, 745-753.

Tzanavaras, P. D., \& Themelis, D. G. (2007). Review of recent applications of flow injection spectrophotometry to pharmaceutical analysis. Analytica Chimica Acta, 588, 1-9.

Udnana, Y., Jakmunee, J., Jayasavati, S., Christian, G. D., Synovec, R. E., \& Grudpan, K. (2004). Cost-effective flow injection spectrophotometric assay of iron content in pharmaceutical preparations using salicylate reagent. Talanta, 64, 1237-1240.

World Health Organization (2007). Quality assurance of pharmaceuticals: A compendium of guidelines and related materials, 2-nd edition, V2, good manufacturing practices and inspection. India: WHO Press.

Zachariadis, G. A., \& Michos, C. E. (2007). Development of a slurry introduction method for multi-element analysis of antibiotics by inductively coupled plasma atomic emission spectrometry using various types of spray chamber and nebulizer configurations. Journal of Pharmaceutical and Biomedical Analysis, 43, 951-958.

Zachariadis, G. A., Raidou, E. S., Themelis, D. G., \& Stratis, J. A. (2002). Determination of mineral content of active dry yeast used in pharmaceutical formulations. Journal of Pharmaceutical and Biomedical Analysis, 28, 463-473.

Zargba, S., \& Hopkata, H. (1996). Spectrophotometric determination of Fe (II) in pharmaceutical multivitamin preparations by azo dye derivatives of pyrocatechol. Journal of Pharmaceutical and Biomedical Analysis, 14, 1351-1354. 